\title{
Transport and Mixing Between the Coastal and Offshore Waters in the Great Lakes: a Review
}

\author{
Yerubandi R. Rao ${ }^{1, *}$ and David J. Schwab ${ }^{2}$ \\ ${ }^{1}$ Environment Canada, Water Science and Technology \\ National Water Research Institute \\ 867 Lakeshore Road \\ Burlington, Ontario L7R 4A6 \\ ${ }^{2}$ Great Lakes Environmental Research Laboratory \\ 2205 Commonwealth Blvd. \\ Ann Arbor, Michigan 48105
}

\begin{abstract}
The Laurentian Great Lakes of North America have horizontal scales of hundreds of kilometers and depth scales of hundreds of meters. In terms of coastal dynamics, they behave much like inland seas and exhibit physical processes characteristic of the coastal oceans. The lakes are dynamically similar to the coastal ocean in that their horizontal dimensions are larger than the vertical dimensions, and the principal source of mechanical energy is the wind. The major difference in dynamical processes is that the lakes are enclosed basins and are not connected to the deep ocean. This paper presents an overview of some of the significant aspects of physical processes in the coastal zones of the Great Lakes. The review is based on examples ranging from lake-wide experiments like the International Field Year on the Great Lakes (IFYGL) to several process-oriented coastal boundary layer experiments. The basic circulations in the nearshore zone and coastal boundary layer are summarized. The review concludes with suggestions for future work on the understanding of the physical processes that would have a bearing on lake management in the coastal zones of the Great Lakes.
\end{abstract}

INDEX WORDS: Nearshore circulation, coastal boundary layer, coastal exchanges, upwelling, downwelling, thermal bar, episodic events.

\section{INTRODUCTION}

The coastal zones of oceans and lakes are truly dynamic ecological systems. At the coastal interface, the sea is shallow and the land is low. Sand and mud flats receive frequent floods and river runoff, while wind and waves bring continual change to the shoreline. However, it is often human activities which cause the greatest and most rapid change, and which are the primary reasons for the concern with coastal resources management. The coastal zone is particularly vulnerable to global changes such as climate change, sea level change, which is in itself a result of climate change, and changes in uses of land and fresh water. These changes may fundamentally modify geomorphologic, hydrodynamic, geochemical, and biological processes in the coastal zone and affect signifi-

\footnotetext{
*Corresponding author. E-mail: Ram.Yerubandi@ec.gc.ca
}

cantly transport of materials from the land to rivers and seas.

The Laurentian Great Lakes represent systems dominated by their coastal nature. While the lakes are large enough to be significantly influenced by the earth's rotation, the lakes are at the same time closed basins which can serve to magnify the influence of coastal processes over coastal marine systems. Nowhere is an understanding of how complex physical, geological, chemical and biological processes interact in a coastal system more important to a body of water than the Great Lakes (Klump et al. 1995). Several physical factors combine to make the coastal systems complex and unique in its hydrodynamics, and the associated physical transport and dispersal processes of the coastal flow field are equally complex. Physical transport processes are often the dominant factor in mediating geochemical and biological processes in 
the coastal environment. Thus, it is very important to have a thorough understanding of the coastal physical processes responsible for the distribution and redistribution of chemical and biological species in this zone. However, the coastal regions are not isolated but are coupled to a greater or lesser degree by exchanges with mid-lake waters involving transport of materials, momentum and energy.

The transport and fate of nutrients and contaminants discharged through sewage outfalls, rivers, and non-point sources into the nearshore zone is one example of the influence of coastal physics on biological processes. The residence time and degree of accumulation of nutrients and contaminants in the sediments (suspended as well as bottom) are partly controlled by the physical exchange processes and partly by biotic processes active in the coastal regions. Many Great Lakes beaches are used extensively for bathing from June through August. But the water along some stretches of shoreline has become polluted, rendering beaches there unfit for bathing. Another example of the influence of coastal physics on biological processes is the introduction of zebra mussels and other species into the lakes. This accidental introduction is playing a major role in changing the ecology of the Great Lakes. Recently, Heckey et al. (2004) hypothesized that the mussel colonization has implications for the removal and fate of materials in the nearshore zone. A third example is the excessive growth of Cladophora which is again becoming a problem along the shores of Lake Erie and Lake Ontario. Although present levels remain relatively low compared to those measured in the 1960s and 1970s, prior to effective phosphorus control in the Great Lakes basin, the fouling of beaches has resulted in increased complaints from residents. Intense earthy/musty taste and odor (T\&O) events have also been occurring for prolonged periods in late summer along the north shore of Lake Ontario (Watson et al. 2002).

Over the last two decades, several workshop reports have summarized the importance and the complex nature of cross-shore and alongshore transport of all materials in the coastal ocean (Brink et al. 1992) and in the Great Lakes specifically (Klump et al. 1995). The reviews by Csanady (1984) and Mortimer (1984) stress the linkages between the Great Lakes physical limnology and coastal oceanography. Boyce et al. (1989) and Murthy and Schertzer (1994) provided succinct reviews of the physical processes with relevance to water quality in the Great Lakes. Csanady (1984) discussed the dynamics and physical processes in shallow seas and over continental shelves and provided several examples from the experimental data in the Great Lakes. Also, the hydrodynamic modeling of the Great Lakes is covered in excellent reviews by Simons (1980) and Schwab (1992). The relation of hydrodynamic modeling to biological and chemical processes is specifically covered in reviews by Boyce (1974) and Bedford and Abdelrhman (1987). Murthy and Rao (2003) reviewed the flow and structure within the coastal boundary layer of the Great Lakes. Some of these studies are based on large scale cooperative efforts between the U.S. and Canada, for example the International Field Year for the Great Lakes (IFYGL), the Lake Erie Binational Study, and the Upper Lakes Reference Study. Although these reviews are excellent sources for the physical limnology of large lakes, they are not intended to provide details of the coastal exchange processes relevant to the problems mentioned above. For example, the intense but relatively small scale wave-driven processes that operate in the innermost region of the coastal zone have not been examined in detail. Recently, two major research projects on the transport and transformation of biogeochemically important materials in the coastal waters of the Great Lakes were completed (Green and Eadie 2004). Also, observational information and numerical modelling capability on the nature of the flow fields has increased since these reviews (Beletsky and Schwab 2001, Rao et al. 2004). Therefore, this review complements the already available literature on this subject. This review will focus on specific mechanisms that contribute the most to the alongshore and cross-shore transport of material under different conditions. Specifically, these are (1) wave- driven processes, (2) coastal boundary layer processes including upwelling and downwelling flows, (3) the thermal bar, (4) episodic events such as storms, and (5) river plumes.

\section{SUB-REGIONS OF THE COASTAL ZONE}

The first characteristic feature of coastal waters is their shallow depth, typically 0-20 m, compared with depths of $100 \mathrm{~m}$ in the open waters of all the lakes except Lake Erie. The State of the Lake Ecosystem Conference (SOLEC) report in 1996 defined the nearshore or coastal zone in the Great Lakes as a zone that begins at the shoreline or the lakeward edge of the coastal wetlands and extends 


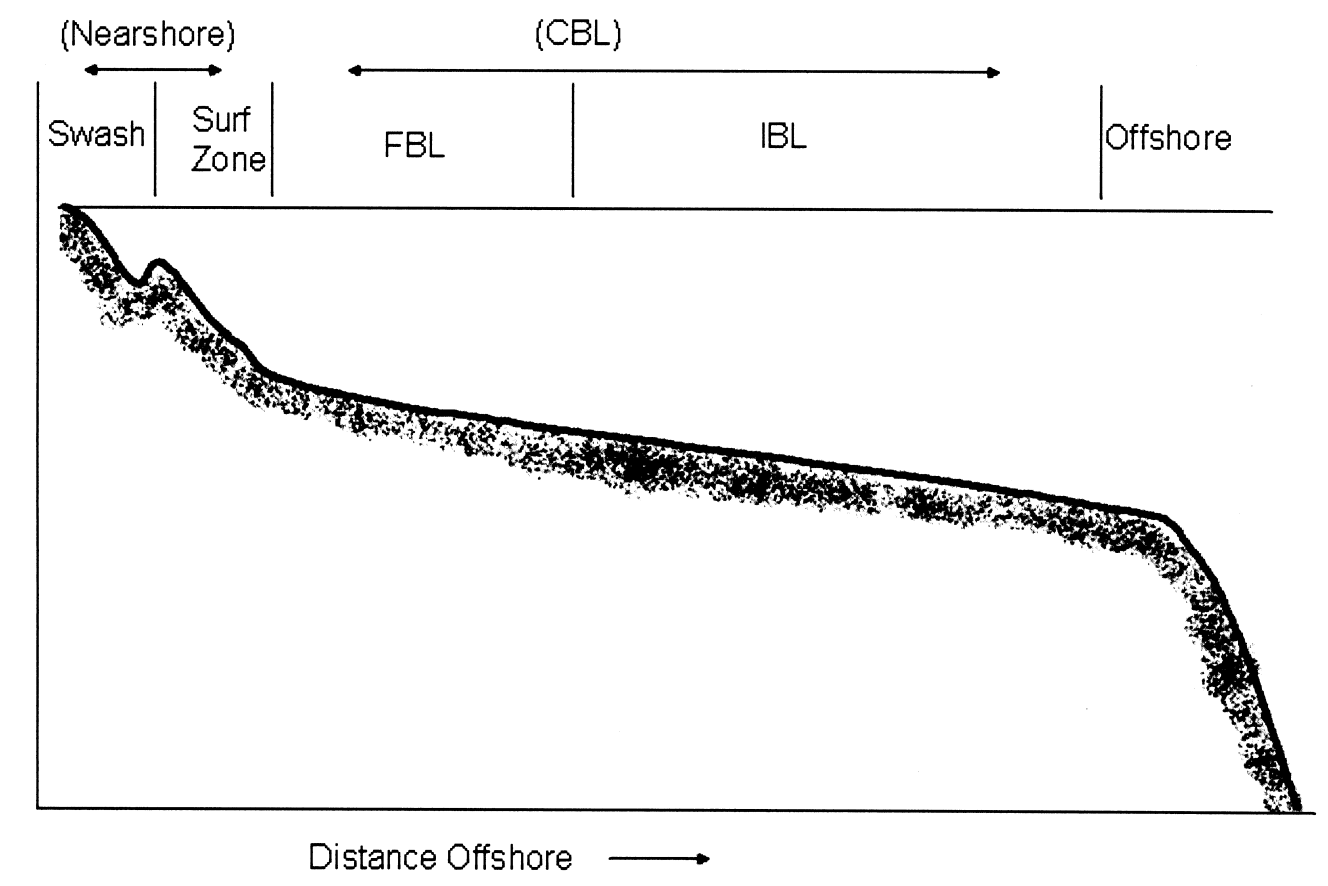

FIG. 1. Schematic diagram of the sub regions of the coastal zone.

offshore to the deepest lake-bed depth contour where the thermocline typically intersects with the lake bed in late summer or early fall. This delineation inherently considers the surf and swash zones in the littoral zone. Because of the presence of the bottom at a relatively shallow depth, currents near the bottom are often much larger than in deeper areas. Bottom friction plays a significant role in nearshore dynamics. The presence of the shoreline acts as a lateral constraint on water movements, tending to divert currents so that they flow nearly parallel to the shoreline. The shoreline also causes surface slopes to develop, which in turn affect water movements. The influx of freshwater run-off from the land affects the density of the coastal water. For a similar heat flux through the sea surface, the shallower water near the coast undergoes larger changes in temperature than deeper water. Because of these effects, coastal waters of the Great Lakes exhibit large horizontal gradients of density, often associated with changes in currents. The Great Lakes also undergo a complete cycle of isothermal to vertically stratified conditions in a year. The thermal structure in the Great Lakes generally depends on the season because of the large annual variation of surface heat fluxes (Boyce et al. 1989). During the unstratified period, storm action is the most important forcing, as higher wind speeds and the absence of stratification allow the wind forcing to penetrate deeper into the water column. In summer and fall most of the lakes are stratified with a distinct thermocline in the upper $30 \mathrm{~m}$.

Boyce (1974) provided time and space scales associated with various motions in the Great Lakes. His summary provided typical scales for different physical processes ranging from $10 \mathrm{~m}$ in nearshore areas for surface gravity waves to 100 s of kilometers for large scale wind driven flows or gravitational seiches. The flow regimes of the coastal zone are not all uniform from nearshore to offshore waters but vary appreciably as water depth changes. For convenience, the coastal zone is divided into three regimes, namely 1) the nearshore area consisting of swash and surf zones, 2) frictional and inertial boundary layers, together known as coastal boundary layer (CBL), and 3) the open lake (Fig. $1)$. In the open lake the momentum imparted by the wind stress is balanced by the Coriolis force, frictional forces are small, and wave-induced bottom agitation is minimal. In contrast, the frictional boundary layer (FBL) is dominated by bottom friction and lateral friction. At around $3 \mathrm{~km}$ from shore an outer boundary layer, known as the inertial boundary layer (IBL), develops due to the adjustment of inertial oscillations to shore parallel flow 
(Rao and Murthy 2001a). Wave run-up and breaking waves are dominant sources of mean flows within the swash and surf zones.

\section{WAVE-DRIVEN PROCESSES}

The wind excites surface waves that can be hazardous to navigation and the main cause of shoreline erosion. The most common direction from which the wind blows over the Great Lakes region is the south-west to west, but in a climate which is extremely variable from day to day, winds from other directions are quite frequent and strong spells of easterly or north-easterly winds are not unusual. As waves respond to meteorological forcing, the wave-induced motions are also mainly episodic. Liu (1999) provided a synopsis of the state of knowledge on wind generated waves in the Great Lakes. Wave hindcasts for the Great Lakes were conducted by Resio and Vincent (1976) and $\mathrm{Hu}$ bertz et al. (1991) for the U.S. Army Corps of Engineers. Donelan (1977) developed a simple and practical wave prediction model for the Great Lakes. Schwab et al. (1984a) adapted this approach for the prediction of Great Lakes waves and developed an operational model known as the Donelan/GLERL wave model. Recently this model was compared with observations from a mid-lake buoy in Lake Michigan. The results showed that the wave model calculated the wave heights well, but consistently underestimated the wave periods (Hawley et al. 2004). Scott et al. (2004) used a second generation spectral wave model to hind-cast the wave climate of Lake Ontario as a part of an overall assessment of shoreline erosion and lake level regulation on the lake. As wind-generated waves propagate from deeper water toward the shore, the decreasing depths begin to influence near-bottom orbital motions, modifying the wave kinematics. Therefore, the greatest effect of wind waves, which are the main cause of shore erosion, occurs in the surf and swash zones. Inputs of storm runoff, combined sewer overflows, and streams occur in a very unsteady manner in this zone. The swash zone with wave run-up and run-down on a beach forms the boundary between the surf zone and the backshore. It also determines the landward boundary of the area affected by the wave action. The surf zone is the area of water between the swash zone and the seaward side of breaking waves. The width of the surf zone is very small compared to the total width of the coastal boundary layer. However, transport processes which operate in this zone are extremely intense and therefore deserve a greater description than provided in earlier contributions. In contrast to other regimes in the coastal zone, the surf zone is severely constrained laterally; therefore the geostrophic effects (steady currents sustained by a balance between the pressure gradient force and the Coriolis force) are negligible. Circulation is driven almost exclusively by forces resulting from the dissipation of breaking waves (Battjes 1988). The net onshore transport of water by wave action in the breaker zone, the lateral transport inside the breaker zone by longshore currents, the seaward return of the flow through the surf zone by rip currents constitute a nearshore circulation system (Holman 1995).

There are several studies that have been conducted in the nearshore zones of the Great Lakes for shore protection measures and most of them deal with fluctuating water levels and coastal erosion. Wave-generated currents, which transport beach material, are an important factor in the beach stability. The direction of littoral drift is determined by the angle of wave approach and associated longshore currents, and is particularly critical during periods of high lake levels. The predominant direction of the littoral drift depends on non-storm waves that contain much more total energy than is contained in storm waves of shorter duration. Wave-generated currents carry some particles along the bottom as bed load, while other particles are carried some height above the bottom as suspended load. Figure 2 a shows general littoral drift directions in the Great Lakes (Carter and Haras 1985).

Except for one or two studies, the ongoing interest in wave research related to economics and navigation (Liu 1999) has not clearly translated into elaborate experiments or models for understanding the wave characteristics in the nearshore zones of the Great Lakes. Schwab et al. (1984b) measured wind, waves, currents, and water levels near Lake Erie's southeastern shore during the fall of 1981 (Fig. 2b). This study showed the influence of offshore currents on the flow regime within the surf zone. They found that within the surf zone, the dominant forces are not only the wind stress and longshore pressure gradient, but also the bottom stress and wave radiation force. They also showed some evidence of currents associated with seiche motions on the surf zone flow regime. Wave orbital motions induced by the surface waves can have a potential for resuspension of bottom sediments in the shallow zones of the Great Lakes and much of Lake Erie. For example, Lam and Jaquet (1976) 


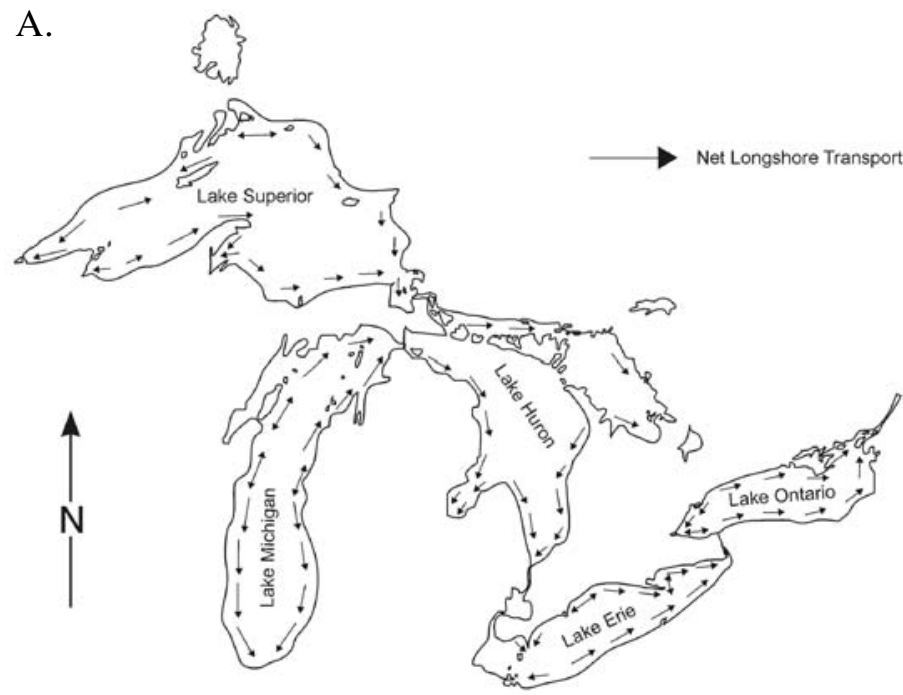

FIG. 2. (a) the net longshore transport directions in the Great Lakes (redrawn from Carter and Haras 1985) (b) Time series of wind, wave potential energy, longshore currents and water level at the south eastern shore of Lake Erie during a storm episode.

used these orbital motions of waves for determining the suspension of sediments and particulate pollutants in lakes. Also Lesht and Hawley (1987), Hawley and Lesht (1995) used instrumented moorings to provide measurements of suspended sediment concentrations in the Great Lakes. More intensive experiments, coupled with long-term deployments, are needed to understand this very important zone in the Great Lakes.

\section{THE COASTAL BOUNDARY LAYER}

The coastal boundary layer is the region between the wave breaking zone and the open lake where frictional forces and the steering affect of the shore are dominant processes. The prime driving force of circulation in this zone is again the wind; however, the effects of stratification can become very important during the summer period. The wind action on coastal waters rapidly generates flow predominantly parallel to the coast. When a steady wind blows along the lake, the equilibrium condition of the water surface is a depression along the upwind end, and increase of elevation (storm surge) along the downwind end of the lake. Surface seiche, which is the oscillatory response of the lake surface after wind cessation, can also have a significant impact on the nearshore circulation in some of the
B.
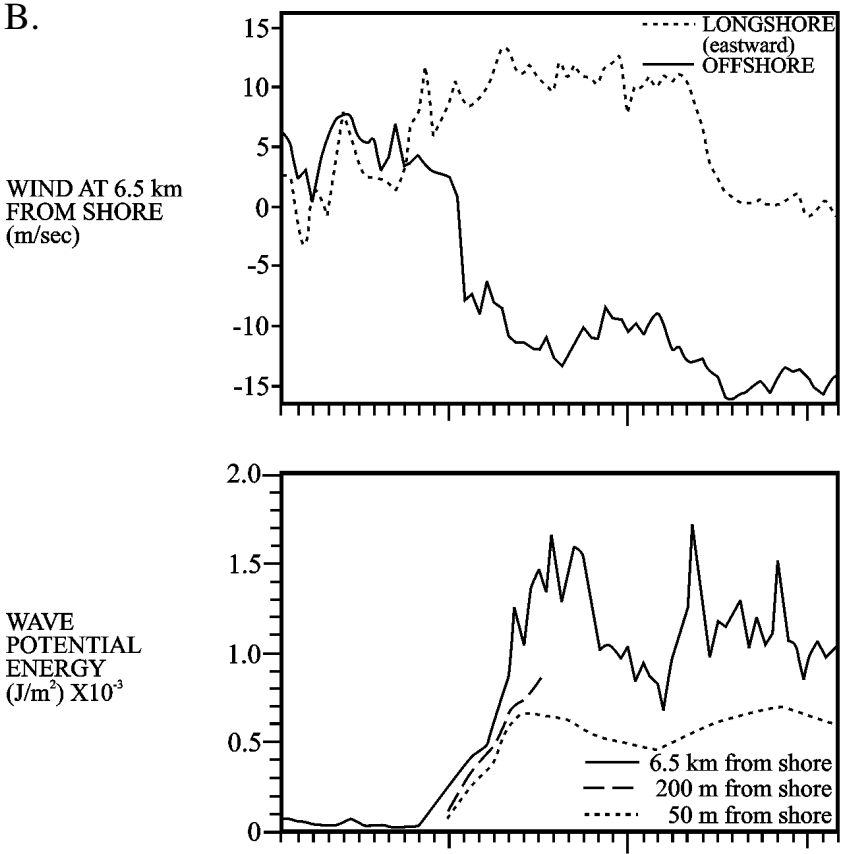

LONGSHORE CURRENT (m/sec) WATER LEVEL (m)
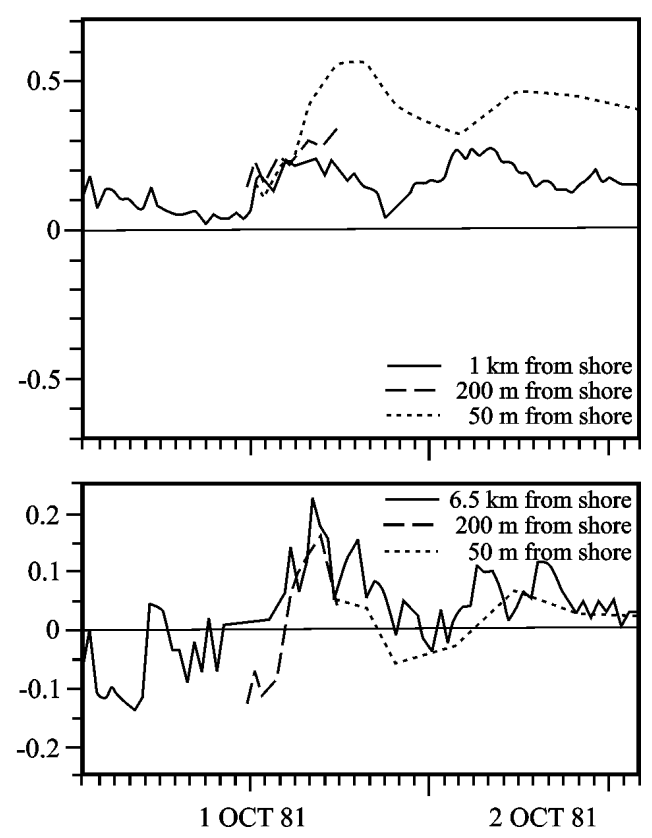

Great Lakes. Storm surges and seiches in the Great Lakes have been described among others by Rao and Schwab (1976), Schwab (1978), and Hamblin (1987). When a steady wind over the homogeneous lake pushes water downwind, the water level rises, and the resultant pressure gradient causes a return flow in the deeper parts of the lake forming two gyres. This type of topographic wave is a vorticity wave that can exist only in the presence of both 
depth gradients and earth's rotation (Saylor et al. 1980). The implications of steady wind-induced motion and its impact on the offshore transport of the material will be discussed in the next section.

Winds at mid-latitudes are usually quite variable, rarely displaying significant persistence for more than a day. Under these circumstances the transient properties of coastal currents are often of greater practical importance than the steady state for constant wind. These transient properties depend on the frequency of weather cycles. A particularly notable feature of coastal currents in the Great Lakes is the presence of inertial oscillations during the stratified period. The inertial effect may be understood with the aid of simple models in which bottom friction is ignored and alongshore wind stress is suddenly imposed at the surface. Any persistent alongshore motion which arises must somehow adjust to geostrophic equilibrium. The period $\mathrm{T}$ of such oscillations is given by $T=2 \pi / f$, where $f$ is the rotational frequency of the earth. At the latitude of the Great Lakes T is close to 17 hours. Although these oscillations are more like an organized flow, because of their oscillatory nature they can be viewed as large-scale fluctuations and as such contribute to dispersal processes in the coastal zone (Rao and Murthy 2001a). In addition to inertial currents, tidal currents of diurnal and semi-diurnal periods are common in the coastal oceans, but not in the Great Lakes. However, in the coastal zones both these types of rotary motion must be modified since the particle velocities perpendicular to the coast must vanish there. Consequently, there is an adjustment zone, typically 5 to $10 \mathrm{~km}$ wide often referred to as the coastal boundary layer (CBL).

During the stratified season significant wind events cause upwelling and downwelling of the thermocline along the shore and within the CBL. If the coast is on the left of the prevailing winds, the wind induced Ekman transport will be away from the coast in the surface layer and upwelling occurs near the coast. During this period an onshore and upslope transport occurs at some depth below the surface. On the other hand, if the coast is on the right of the wind downwelling occurs. The transport in the surface layer is towards the coast, and offshore transport occurs below the surface layer. The changeovers from upwelling to downwelling regimes and vice-versa are of particular interest to nearshore biology and chemistry studies. The offshore distance scale over which these events takes place depends on the wind stress and nearshore bathymetry (Csanady 1984) and is known as the
Rossby radius of deformation (typically of the order of 3-5 km). In this zone a balance exists between wind stress, Coriolis force, and internal pressure gradient. A typical changeover from upwelling to downwelling is accompanied by marked changes in the thermal structure in this zone in a period of 4-5 days, exposing the zone to either epilimnetic water or hypolimnetic water depending upon the situation. Upwelling and downwelling have the potential to produce large onshore-offshore transport of material.

During the stratified season in the Great Lakes two types of internal waves often occur after a strong wind event: Poincaré waves and internal Kelvin waves. Poincaré waves are basin-wide oscillations of the thermocline characterized by anticyclonic phase propagation. These waves were first observed in the Great Lakes by analyzing temperature observations at municipal water intakes for cities around Lake Michigan (Mortimer 1963). On the other hand, internal Kelvin waves are coastally trapped oscillations of the thermocline that progress cyclonically around the lake. During periods of calm or weak meteorological conditions, coastal currents are usually weak. During these periods effluent from shoreline sources tend to hug the shore, with limited cross-shore dispersion, leading to conditions of coastal entrapment (Csanady 1970). Blanton and Murthy (1974) also observed that the current shear in the lateral direction may sometimes cause rapid mixing of water in the CBL. Several field experiments have been conducted to understand the flow and structure of the CBL in the Great Lakes (Csanady 1972, Murthy and Dunbar 1981).

The mean summer circulation in the coastal zone of Lake Ontario was obtained from daily transect data collected during the International Field Year on Great Lakes (IFYGL) in 1972 (Aubert and Richards 1981). Clear examples of coastal jets were observed in Lake Ontario during IFYGL. Coastal jets are generated by alongshore wind stress impulses and are associated with the thermocline displacements (Csanady and Scott 1974). Although some important features of mean flow pattern were explained using these data and simple equilibrium models, many discrepancies were observed later between model results and measurements owing to transient upwelling and downwelling events during summer. In the Great Lakes the coastal upwelling and downwelling induced by local winds and propagation of these events as internal Kelvin waves have also been studied by using both field data and numerical models (Simons and Schertzer 1989, Beletsky et al. 

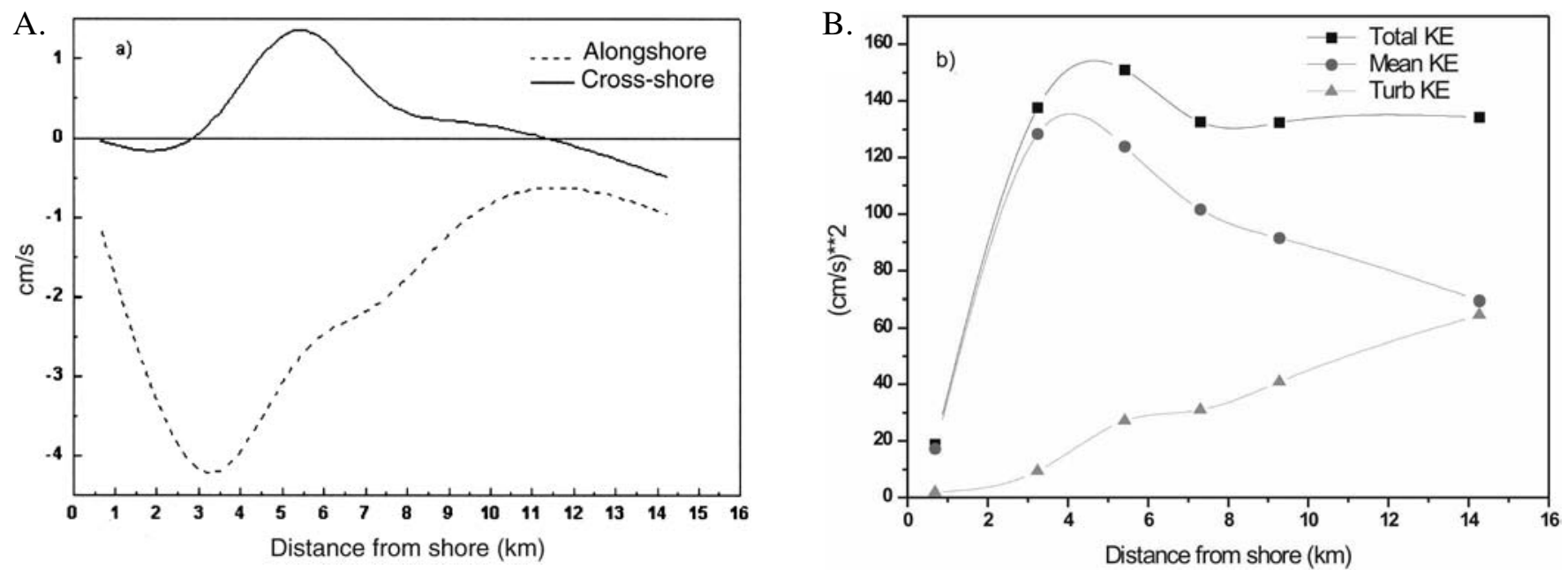

FIG. 3. (a) Mean alongshore and cross-shore components of currents and (b) Components of kinetic energy (total, mean, and turbulent) with distance from shore in Lake Ontario.

1997). Recently, Rao and Murthy (2001a) provided a description of the structure of flow within the coastal boundary layer during the summer regime and its variation during the upwelling/downwelling events using simultaneous Eulerian (current meter) and Lagrangian (drifter) currents in Lake Ontario.

Figure $3 \mathrm{a}$ shows the variation of mean crossshore and alongshore current components with distance from shore during summer in Lake Ontario. The mean alongshore currents were toward the west and peaked at a distance of $3 \mathrm{~km}$ from shore. The observed westward mean flow of 3 to $4 \mathrm{cms}^{-1}$ was consistent with earlier observations of mean cyclonic circulation in large lakes. Csanady (1984) attributed this flow to the persistence of a domed thermocline in summer due to the influence of prevailing winds. The cross-shore velocity increases with offshore distance and peaks at about $5 \mathrm{~km}$ from shore. The cross-shore velocities are smaller than alongshore component by a factor of 5 or so. The domed thermocline in coastal waters is evidence of adjustment to geostrophic equilibrium provided by cyclonic circulation with mean surface flow. From a waste disposal point of view, the worst situations are the low energy regimes, where the discharged effluents may form stagnant pools with very little transport and mixing. Therefore, a climatological classification of the flow regime can provide a description of the energetics of the coastal boundary layer. Figure $3 \mathrm{~b}$ shows the components of kinetic energy (total, mean and fluctuations) as a function of offshore distance. The mean flow kinetic energy (MKE) dominates within 8-10 $\mathrm{km}$ from the shore. Fluctuating kinetic energy or turbulent kinetic energy (TKE) increases with offshore distance, as near-inertial oscillations become dominant offshore. In summer the MKE increases offshore to a peak at about $3 \mathrm{~km}$ from shore then decreases further offshore. Murthy and Dunbar (1981) characterized this flow regime, where total kinetic energy or mean current increases to a peak in the frictional boundary layer. Within this zone the currents are influenced by bottom and shore friction. Most of the sewage outfalls in the Great Lakes discharge treated effluents within $2 \mathrm{~km}$ from the shore. In this zone stagnant or weak currents could lead to situations of persistent trapping of effluents (coastal entrapment). Beyond $3 \mathrm{~km}$, due to the adjustment of inertial oscillations to shore parallel flow, an outer boundary layer develops, known as the inertial boundary layer. The effluents released in this zone can be potentially transported and mixed better with offshore waters than in the FBL. The combination of these zones (FBL+IBL) forms the coastal boundary layer.

Experiments conducted on the Great Lakes showed that significant mass exchange between the CBL and offshore waters takes place during episodic events and the current reversals associated with the propagation of internal Kelvin waves. Complex patterns of cross-shore transport have been observed in upwelling systems including the Great Lakes (Blanton 1975, Csanady 1984). In some limited experiments, Lee and Hawley (1998) studied the response of suspended particulate material to upwelling and downwelling events in south- 
ern lake Michigan In the above-mentioned Lake Ontario experiment, the horizontal exchange coefficients for the flow were also obtained by Eulerian measurements during several episodic events in the summer season. During the upwelling period, the statistics show that the alongshore exchange coefficients were slightly higher than cross-shore components in the first $5.5 \mathrm{~km}$ from the shore, i.e., in the FBL. The cross-shore components reached a peak at around $6-7 \mathrm{~km}$ from shore and remained steady outside the CBL. These results indicate that momentum transfers occur in the alongshore direction in the FBL and cross-shore transfers may dominate in the IBL. The cross-shore exchange coefficients in the surface levels were lesser than sub-surface values in the IBL. During the downwelling circulation the alongshore components were higher in the CBL, and outside the CBL the cross-shore exchanges were dominant. The turbulent momentum exchanges were rather small in the FBL, but significantly increased in the IBL.

Hydrodynamic models of the coastal boundary layer provide a comprehensive view of its characteristics under a broad range of forcing conditions. Bennet and Lindstrom (1977) developed an empirical forced wave model for currents and thermocline displacements in the coastal boundary layer of Lake Ontario. Their model was able to explain the phase speeds of internal Kelvin wave and topographic waves in the lake. Simons (1984) and Murthy et al. (1986) developed an impulse response function model for studying Lake Ontario winter circulation. Although these simple methods proved to be efficient during homogeneous conditions, their utility for predictive purposes is rather limited. Hayashida et al. (2000) used an explicit finite element hydrodynamic model to study the nearshore flow near the mouth of the Niagara River. They observed that a spatial resolution of less than $100 \mathrm{~m}$ is needed for modelling nearshore flow structure. Recently Shen et al. (1995) developed a fine-resolution nested three-dimensional hydrodynamic model to study the currents and pollutant transport in the nearshore area along the north shore of Lake Ontario. Sheng and Rao (2006) demonstrated that nested-grid hydrodynamic models are suitable to predict circulation and thermal structure in the coastal boundary layer. In another approach, Lee et al. (1996) used a fine resolution finite element model for the nearshore area of the City of Milwaukee in Lake Michigan. Rao et al. (2003c) studied the impact of sewage discharges from a proposed outfall in the western Lake Ontario using a combination of physi- cal limnological data and mathematical models. They used a type of objective analysis, which consists of interpolation of currents by radii of influence around the observed points (Lam et al. 1984). With the recent increases in computing power coupled with the real-time availability of data from observing systems, experimental forecasting and prediction systems have been implemented for the Great Lakes (Schwab and Bedford 1994). This system is based on a three-dimensional ocean circulation model developed at Princeton University for coastal ocean application by Blumberg and Mellor (1987). The horizontal and vertical resolution of these models is being improved to better represent the coastal boundary layer.

\section{STORMS IN WINTER AND SPRING}

During fall and winter seasons, the higher wind speeds and the absence of the thermocline allow the effects of wind action to penetrate deeper into the water column. In the Great Lakes, the gradients of many biogeochemically important materials are considerably higher in the offshore direction than in the alongshore direction (Brink et al. 1992). In the presence of these large gradients, cross-isobath circulation is a primary mechanism for the exchange of material between nearshore and offshore waters. The southern basin of Lake Michigan is subjected to recurrent episodes of sediment resuspension caused by storm induced waves and currents (Mortimer 1988). These resuspension events are suggested as the main mechanism for reintroducing nutrients and contaminants stored in sediments into the water column (Eadie et al. 1996). The resuspension events are evident in satellite imagery as well as turbidity records from municipal water treatment plants around the lake. Spring and fall storms can create a nearshore zone of turbid water up to $10 \mathrm{~km}$ wide which sometimes encompasses the entire southern basin of the lake. Much of the resuspended material consists of fine-grained silty clay that can remain in suspension for several weeks after a storm. The total estimated amount of material resuspended during a large event can be comparable to the total annual load (erosion, atmospheric deposition, and tributary input) of fine-grained material to the entire basin (Lou et al. 2000).

Circulation in Lake Michigan is also highly episodic with the most energetic currents and waves occurring during storms. In the shallow waters of the southern basin of Lake Michigan, the water near the coasts moves in the direction of the wind, while 

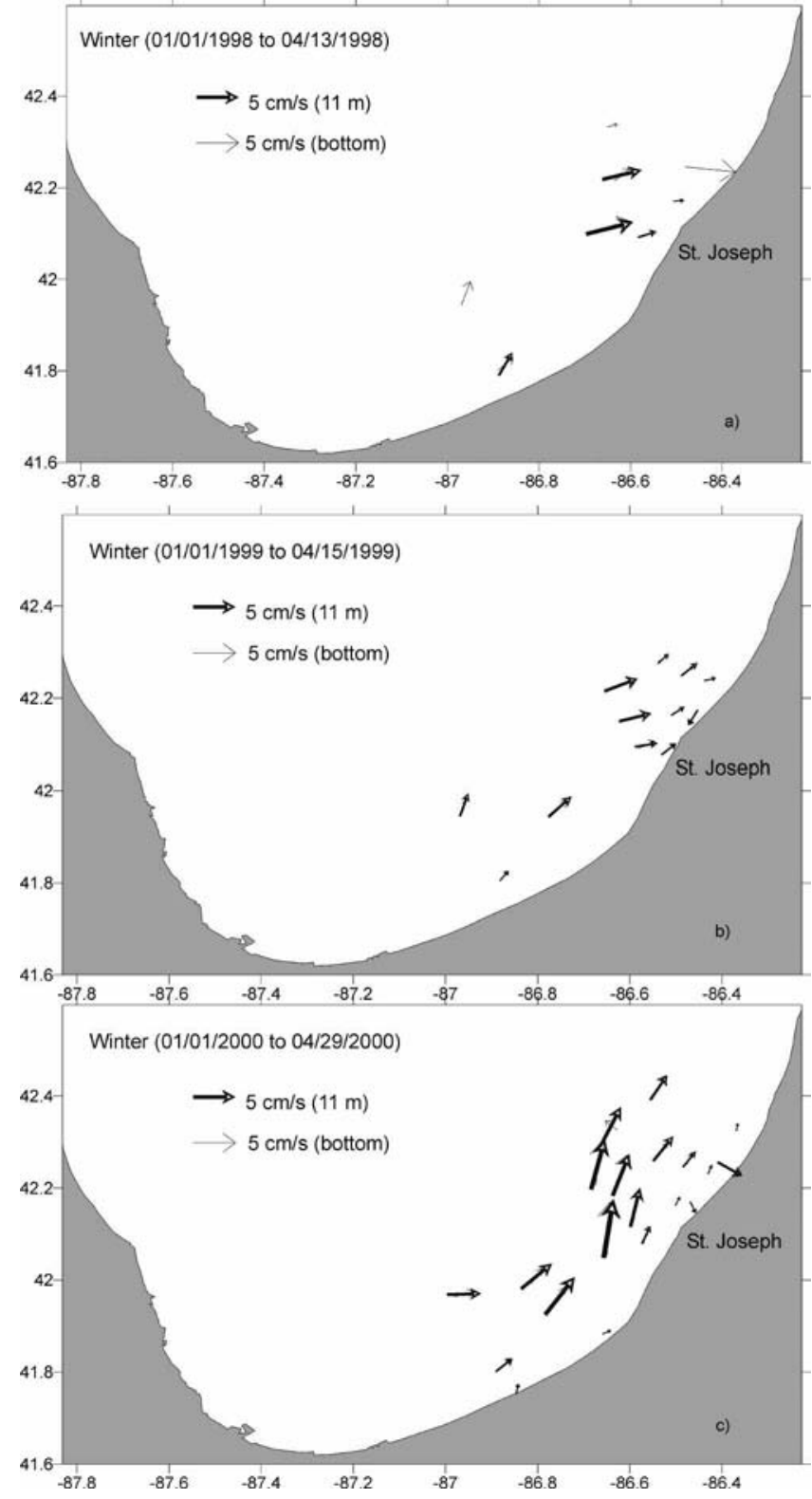
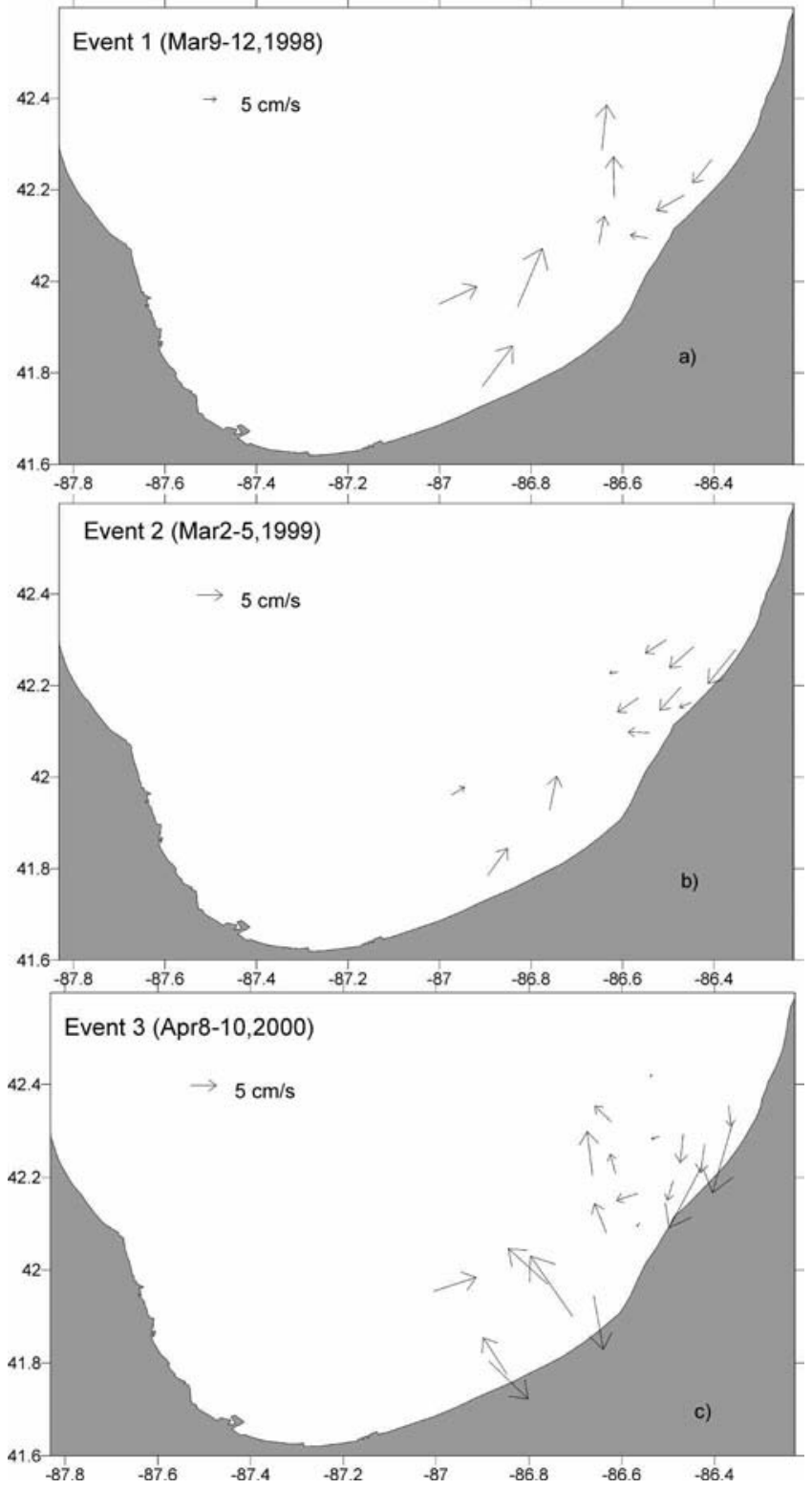

FIG. 4. (a) Vector averaged surface and bottom currents observed in southern Lake Michigan during the winters of 3 EEGLE field years and (b) during three northerly storm events.

return flow occurs in the deeper parts of the lake with a relatively uniform over-lake wind field. This process forms two counter-rotating closed gyres, a cyclonic gyre to the right of the wind, and an anticyclonic gyre to the left (Saylor et al. 1980). The simple two-gyre circulation pattern can be modified to a single gyre cyclonic circulation by lake stratification or vorticity in the wind field (Beletsky and Schwab 2001). These rotary motions are one of the important mechanisms for nearshore-offshore trans- port in the Great Lakes. Schwab et al. (2000) simulated the generation of a two-gyre circulation pattern during the March 1998 northerly wind event in their numerical experiments.

Rao et al. (2003a) summarized the mean and fluctuating coastal currents in southeastern Lake Michigan during the winter and early spring during the 3 field years of the Episodic Events Great Lakes Experiment (EEGLE). The winter-spring currents in this region are quite depth-independent, and the 
vortex mode identified earlier in offshore waters is also evident in the data from these coastal waters. The net seasonal currents during the winter season flow predominantly alongshore and towards the north (Fig. 4a). Time varying alongshore circulation is more closely tied to the alongshore component of the wind. The net offshore transport appears to be a result of the combination of wind-forced two-gyre circulation, Ekman veering of bottom boundary layer currents, and the topographic steering. However, the interannual variability of current speeds and magnitudes seems to be caused mainly by variability of surface wind forcing. The intermittent episodic circulation influenced by northerly storms causes significant asymmetry in the mean circulation pattern (Fig. 4b). During northerly storm episodes the mean current speeds increased significantly, and the currents within $10 \mathrm{~km}$ of shore followed the surface wind stress, while further offshore the circulation was oppositely directed. There is also significant variability of circulation from one storm to another. It appears that the alongshore currents were initially driven by strong northerly wind pulses, but subsequently reverse direction as the forcing stops. The two-gyre circulation seems to be an important mechanism for the relaxation of currents as well as the offshore transport in the southern Lake Michigan. Directly windforced offshore transport was observed in some regions. Furthermore, these observations also suggested that the topographically steered coastal currents in combination with the counter-clockwise veering of bottom boundary layer currents are other important mechanisms contributing to the offshore transport.

\section{THE THERMAL BAR}

The thermal bar is a downwelling plume of freshwater at the temperature of maximum density $\left(4^{\circ} \mathrm{C}\right)$, and is formed in temperate lakes in spring and fall when waters on either side of the $4^{\circ} \mathrm{C}$ isotherm mix (Fig. 5). There have been a number of field investigations of the thermal bar in the Great Lakes and other large lakes (Moll et al. 1993, Gbah and Murthy 1998). The thermal bar phenomenon regularly occurs in the Great Lakes, and was first reported by Rodgers (1968) in Lake Ontario. The density-induced horizontal circulation in large temperate lakes of the northern hemisphere is counterclockwise in the stably stratified nearshore region, and clockwise in the deep water region. The secondary circulation, perpendicular to the primary

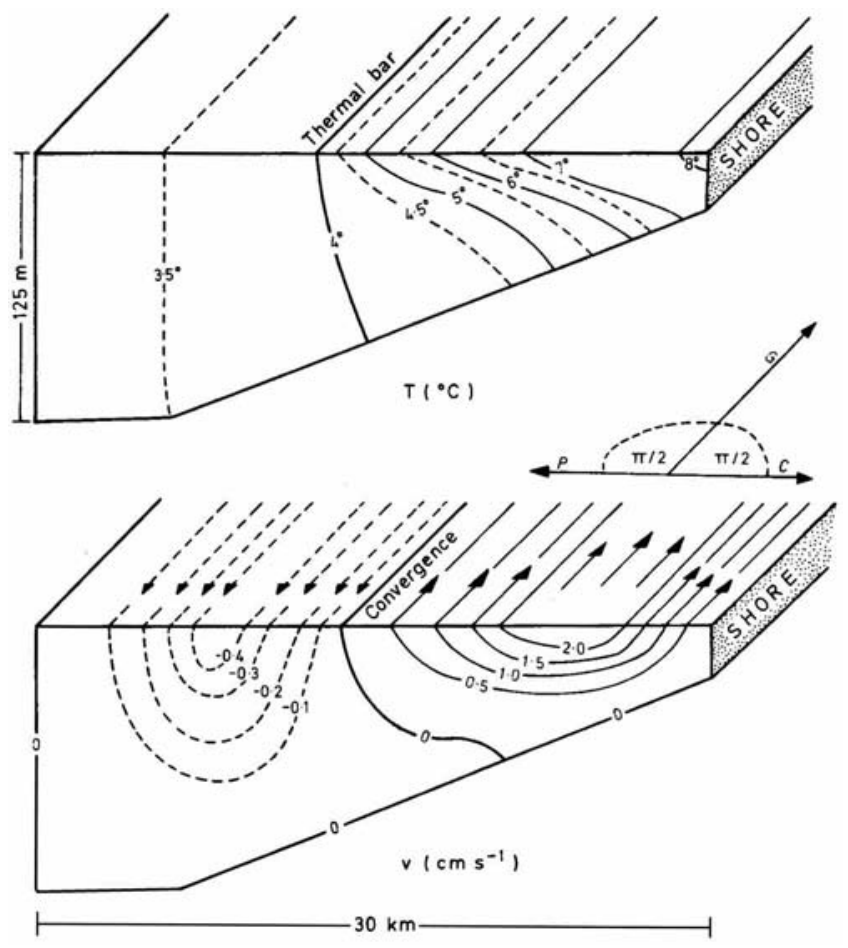

FIG. 5. Schematic diagram of the spring thermal bar (from Henderson-Sellers 1984).

one, consists of two circulation cells, one on each side of the $4^{\circ} \mathrm{C}$ isotherm, where coastal and offshore waters mix and descend. This two-cell thermal bar circulation is important because of its role in inhibiting the horizontal exchange of water between the nearshore and offshore regions. The thermal bar can significantly affect the flow and thermal characteristics of the Great Lakes and may have significant influence on their ecological functioning (Scavia and Bennet 1980). This effect is extremely important because a proper understanding of an ecosystem's interaction with the hydrodynamics is required to determine optimum nutrient loadings to the lake. Holland and Kay (2003) provided an overview of the thermal bar characteristics. Because of the renewed issue of abundant Cladophora fouling beaches each summer in Lake Ontario, an elaborate experiment has been conducted in Lake Ontario during the spring of 2003 (Rao et al. 2004). The data obtained from this experiment offered the opportunity to carry out a detailed analysis of circulation and mixing during the spring thermal bar in Lake Ontario.

In the study by Rao et al. (2004), earlier observations that the observed circulation within a zone be- 



FIG. 6. Measured temperature (in $\left.{ }^{\circ} \mathrm{C}\right)$ distributions along the cross-section off Oakville, Ontario from vessel surveys on (a) 30 April (day 120), (b) 8 May (day 128), (c) 14 May (day 134), and (d) 26 May (day 146). The average wind speed (ws), wind direction (wd), and current profiles for the survey period are inserted on each figure.

tween the shore and the thermal bar is predominantly shore-parallel, and towards the west (i.e., counter-clockwise) were confirmed. The flow away from the thermal bar to offshore showed clockwise circulation on a few occasions. In the 2003 Lake Ontario experiment (Rao et al. 2004) the coastal circulation was mainly influenced by the alongshore winds. One of the interesting observations in this experiment is that the thermal bar was stationary for several days (Fig. 6). Although mean crossshore flow decreased during the thermal bar period, the flow was depth-dependent. In general, theoreti- cal models over-estimated the progression rate of the thermal bar during the early phase. In the later phase, the models that incorporated the effect of horizontal heat flux in the thermal bar region were able to predict the significant increase in the progression rate. This study concluded that the effect of wind on the thermal bar seems to be an important feature and the models have to incorporate this effect. Also, the horizontal turbulent exchange parameters showed non-isotropic conditions in the shallow stably-stratified region. The alongshore horizontal exchange coefficients were higher than 
cross-shore exchange coefficients. During the thermal bar period the magnitude of both alongshore and cross-shore exchange coefficients decreased when the bar was in the nearshore zone. In contrast to an earlier study (Gbah and Murthy 1998) from mid-depth onward the thermal bar has not shown any impact on alongshore exchange coefficients, but cross-shore exchanges decreased marginally. Although this supports the hypothesis that the thermal bar plays an important role in suppressing the horizontal mixing in the shallow depths, its impact is not that significant in deep offshore areas. As suggested earlier, the lateral current shear between the nearshore and the thermal bar region could be an important factor in maintaining the horizontal exchanges in the deeper waters (Blanton and Murthy 1974). The vertical exchange coefficients observed during the thermal bar are comparable to the high values observed during significant upwelling episodes in Lake Ontario (Rao and Murthy 2001b). The high values in the water column were due to the convective mixing during the thermal bar. During the evolution of the spring thermal bar, the vertical mixing decreased considerably in the nearshore regions under stable stratification, whereas, the high vertical mixing levels continued in the offshore region for a longer period.

\section{RIVER PLUMES}

Discharge from the rivers contains sediments, nutrient and pollutant loads that can have significant adverse impacts on water quality near the river mouth in the receiving lake. Horizontal mixing and dispersion of a river plume in shallow receiving basins are key processes which affect the distribution and fate of water-borne material. The mixing of river plumes has been widely studied in the past few decades using numerical models. Most of the numerical modelling work was concentrated on a fresh water plume discharged into salty sea water. In the marine coastal environment, baroclinic and tidal forces dominate river plume transport. Surface trapped river plumes are important features, carrying freshwater, nutrients, and pollutants into the coastal ocean. However, there have been relatively few numerical studies on river plume transport in the Great Lakes (Paul and Lick 1974, Murthy et al. 1986, Stepien et al. 1987). One of the reasons could be that in numerical modeling of river plume transport, one often has to deal with open water boundaries without sufficient measurements to adequately describe the boundary conditions. It is much more difficult to reconstruct the open boundary conditions for wind induced flow than for tide driven currents because of the irregularity of wind driven current. Obviously, the effects of buoyant forces on plume transport in a lake are much weaker compared to the oceanographic settings, even though both the positively and negatively (Masse and Murthy 1990, Churchill et al. 2003) buoyant river plume were observed in large lakes due to temperature differences and particle concentrations of river discharges. In this section two examples will be discussed. The first case involves the influence of large inflows from the Niagara River in Lake Ontario. The second case examines the impact of a low discharge river, the Grand River in Lake Erie.

Water-quality analyses of the Niagara River have shown high concentrations of toxic chemicals that are introduced into Lake Ontario. Much research has been conducted to investigate the dynamics of the Niagara River inflow into Lake Ontario. The nearshore thermal structure is altered significantly by the inflow, the warmer Niagara River plume extends beyond the river mouth in excess of $10 \mathrm{~km}$, after which it eventually mixes with the ambient lake water. The vertical extent of the Niagara River plume can be $8 \mathrm{~m}$ to $10 \mathrm{~m}$, with the warmer inflowing water developing a frontal structure as it enters the lake (Murthy et al. 1986). The gradient across the thermal front depends on the time of year and therefore on the difference between the temperature of the inflowing water and the ambient lake temperatures.

Prevailing wind conditions and lake circulation patterns determine the spread of the Niagara River plume in Lake Ontario (Masse and Murthy 1990). In most circumstances, a plume develops from the Niagara River mouth and tends to extend eastward along the south shore of the lake (Fig. 7). In the initial phase, horizontal velocities from the Niagara River mouth are reduced significantly, and the river water is vertically well mixed over the shallow bar area. Beyond this initial phase, the river plume is deflected in response to lakewide circulation and the prevailing winds. In the transition phase, a large clockwise eddy between 10 and $12 \mathrm{~km}$ in diameter is formed to the east of the Niagara River mouth. The eddy appears often and lasts for a few days. From a water-quality standpoint, river outflow that is entrained into this zone of low net transport is effectively isolated from the mixing effects of the main shore-parallel currents. Consequently, this nearshore area can be a zone in which fine particulate material is deposited. 


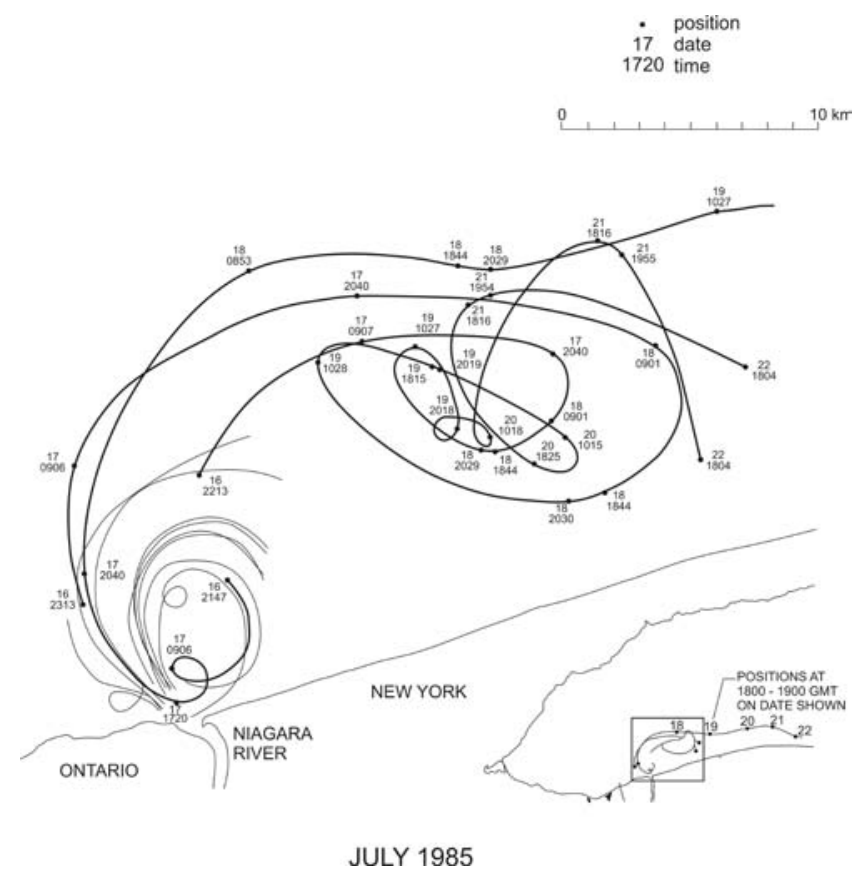

FIG. 7. Trajectories of drifters released near the Niagara river mouth during 16-22 July 1985.

The Grand River provides the major inflow to the eastern basin of Lake Erie and is the largest river system entering the north shore of Lake Erie (He et al. 2006). The drainage area of the Grand River includes rural areas and several urban centers. At its mouth the Grand River is about $250 \mathrm{~m}$ wide and 6 $\mathrm{m}$ deep. Beyond the mouth the bathymetry slopes gently with the $20 \mathrm{~m}$ depth contour at about $4.5 \mathrm{~km}$ from the shore. The Grand River plume has been identified as one of the main sources affecting the water quality of the surrounding area. Figure 8 shows an example of concentrations of conductivity derived from the Grand River plume on 17 May 2005. During the spring time the water column is not quite stratified and the average inflow is around $150 \mathrm{~m}^{3} \mathrm{~s}^{-1}$. The temperature difference in the water column was less than $5^{\circ} \mathrm{C}$ during most of the time. The flow pattern in the lake was mainly dominated by wind-induced circulation which consists of many eddies. During this period the river plume does not behave like a jet, and flow is mixed and remains at its depth of neutral buoyancy. The earth's rotational effects were not important in the Grand River plume dynamics. It is clear from this example that the dynamics and characteristics of small rivers and tributaries are significantly different. Therefore, more studies are required to understand the affects of river plumes on the water-quality of the nearshore waters of lakes.

\section{DISCUSSION AND FURTHER STUDIES}

During the last 30 years investigations of the flow structure and mixing in the coastal zones of the Great Lakes have ranged from lake-wide experiments like IFYGL to several process-oriented coastal boundary layer experiments like EEGLE. Based on these experiments and models, a review of selected coastal physical limnological processes

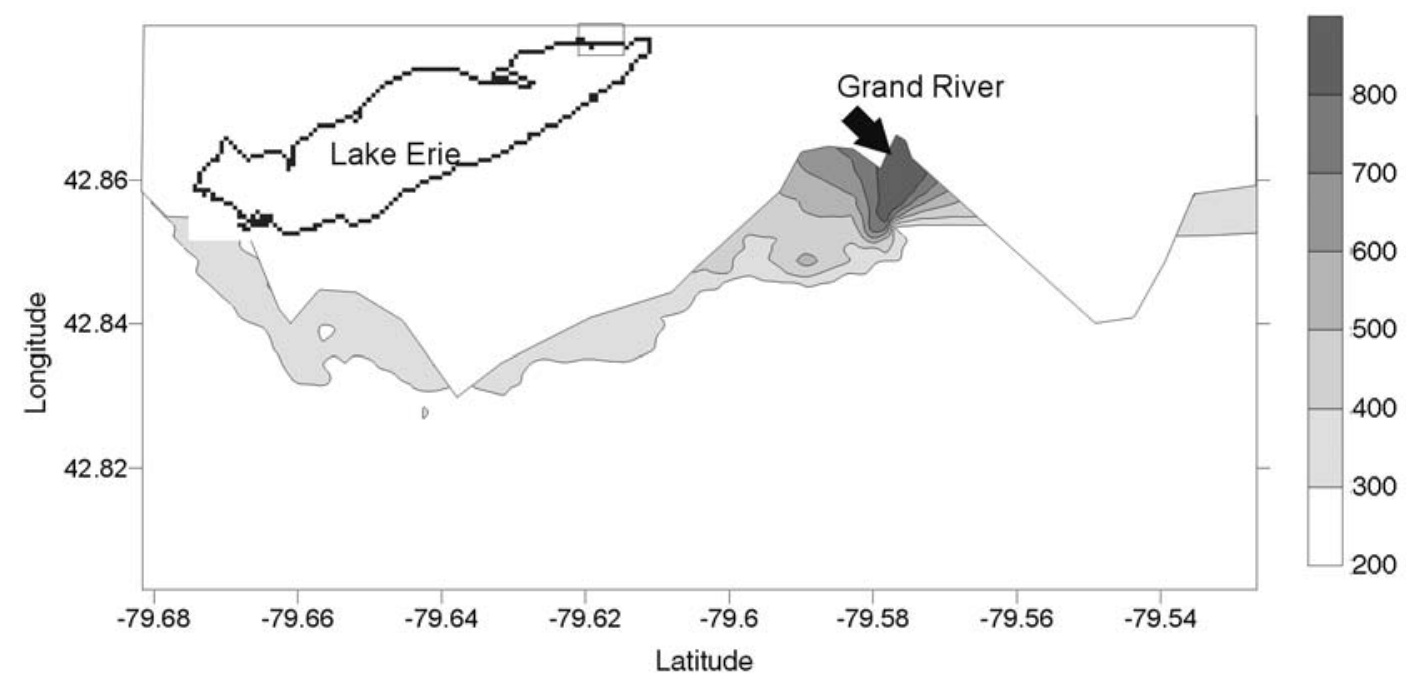

FIG. 8. Observed conductivity distribution of Grand River plume near the river mouth in the eastern basin of Lake Erie on 17 May 2001. 
that would have a bearing on the waste management concepts in the Great Lakes has been presented. The primary focus was to discuss the cross-shore exchange mechanisms in the coastal zones of the Great Lakes. The physical processes in the coastal waters of the Great Lakes are extremely complex and episodic. Among the general factors that influence cross-shore transport and mixing processes are the coastal bathymetry, meteorologically forced events, stratification, inflows and influence of the earth's rotation. As Boyce (1974) noted, all these forcings act together, and we have to gain knowledge of the sum of their actions. In general, our understanding of the flow field in immediate vicinity of the coastal boundary continues to improve with the accumulation of excellent data sets.

Investigations of the nearshore circulation in the zone where waves shoal and break remain a high priority area. Not mentioned in the review but of increasing importance is the impact of nutrient rich groundwater and its interaction close to the shoreline. Ground water and surface water interaction affects water chemistry, especially dissolved solids and nutrients, temperature and dissolved oxygen. Crowe and Shikaze (2004) noted that ground water flow regimes adjacent to coastal wetlands of the Great Lakes are highly transient and vary significantly. More observations and modeling studies will improve our understanding the mechanisms and interactions of these waters. Although several attempts have been made to develop predictive models of sediment resuspension, we are still a long way from having predictive understanding of the dynamics of sediment, contaminant, and pathogen transport near beaches. Recent advances in technologies and techniques provide potential for new observations of the critical features of the waves, turbulence, and suspended sediment regimes. Intensive experiments, coupled with long-term deployments are needed to understand this very important zone in the Great Lakes. The wealth of experimental data in the outer coastal boundary layers of the lakes and the recently concluded EEGLE experiment in Lake Michigan will help to develop a clear understanding and forecasting models for the hydrodynamics of the Great Lakes. Extension of these models to cases of wave propagation and circulation with the complex nearshore bathymetry is the next logical step. Limitations in our understanding of the overall system affect not only our time horizon for system predictability, but even our knowledge of the basic phenomenology that we need to model.
Rao et al. (2003b) found evidence that within the coastal boundary layer upwelling and downwelling events play a major role in delivering the earthy/ musty taste and odour ( $\mathrm{T} / \mathrm{O})$ causing compound, Geosmin, to the water intakes in western Lake Ontario. Studies have indicated that Geosmin is produced in warm surface waters by cyanobacteria during the calm weather conditions followed by upwelling along the northshore of Lake Ontario. During this brief period, the limited observations noted an increase in stability due to weak turbulence in the upper layers of outer boundary layer. In large lakes, Lorke et al. (2005) observed that high-frequency internal waves were generated in the littoral zone with the passage on basin-scale internal Kelvin waves. The role of these small scale mixing processes on the biology have not been studied in the Great Lakes.

There are a number of storm sewers and water courses which directly discharge at the shoreline of the Great Lakes. The urban and agricultural runoffs are associated with contaminants and nutrients during a runoff event. Therefore, significant variations in flow volume and contaminant concentrations will occur during this period. These loads are partly responsible for elevated nutrient and contaminant levels in the nearshore areas of the Great Lakes. During spring, the thermal bar circulation can have an impact on the distribution of dissolved and suspended material within the nearshore zone. Spring runoff, which is enriched with chlorides and nutrients, will most likely be advected by strong alongshore currents as the transport perpendicular to the coastline is extremely limited during this period. Also the descending water column associated with the thermal bar mixes substances vertically, potentially delaying their flushing to the deeper parts of the lake. Water chemistry data show the concentrations of nutrients and chloride are higher inshore versus offshore of the thermal bar. Further studies using non-linear numerical models to investigate the trapping of nutrients derived from land discharges should be continued.

It has been shown that the discharge from the rivers and tributaries will have adverse impacts on water quality not only near the river mouths, but also in the entire receiving lakes. Horizontal mixing and dispersion of river plumes in shallow receiving basins are key processes which affect the distribution and fate of water-borne material. Understanding these mixing processes is of critical importance for effective environmental management of these regions which often support important biological 
resources and are heavily impacted by human activities.

Climate change is increasingly being recognized as a major concern with a potential to affect the physical, chemical and biological characteristics of the Great Lakes. While there are a few studies focused on these aspects (Lam and Schertzer 1999), we have not included those in this review, mainly because of the limitations and uncertainties in the predictions. Nevertheless, the climate change implications (for example, decreases in lake levels and wind speeds) will play a significant role in the coastal hydrodynamics. As shown in this overview, in order to develop long-term concepts for management and conservation of the coastal zones of the Great Lakes, several interrelated objectives have to be considered. First, the complexities of the coastal environment, for example, the episodic nature of flows, have to be recognized for developing the management models of the system. Secondly, there is a need for ongoing research to understand and predict the various manifestations of the coastal processes in the Great Lakes.

\section{ACKNOWLEDGMENTS}

Murray Charlton and Raj Murthy of National Water Research Institute reviewed the earlier version of the manuscript and suggested several improvements to the paper. Todd Howell of Ontario Ministry of Environment provided data for the Grand River Plume.

\section{REFERENCES}

Aubert, E.J., and. Richards, T.L. 1981. IFYGL-The International Field Year for the Great Lakes, Ann Arbor, MI, NOAA.

Battjes, J. A. 1988. Surf-zone dynamics. Ann. Rev. Fluid Mech., 257-293.

Bedford, K.W., and Abdelrhman, M. 1987. Analytical and experimental studies of the benthic boundary layer and their applicability to near bottom transport in Lake Erie. J. Great Lakes Res. 13:628-648.

Beletsky, D., and Schwab, D.J. 2001. Modeling circulation and thermal structure in Lake Michigan: Annual cycle and interannual variability. J. Geophys. Res. 106(C9):19,745-19,771.

, O’Connor, W.P., Schwab D.J., and Dietrich D.E. 1997. Numerical simulation of internal Kelvin waves and coastal upwelling fronts; J. Phys. Oceanogr. 27: 1197-1215.

Bennet, J.R., and Lindstrom, E.J. 1977. A simple model of Lake Ontario's coastal boundary layer. J. Phys. Oceanogr. 7:620-625.
Blanton, J.O. 1975. Nearshore lake currents measured during upwelling and downwelling of the thermocline in Lake Ontario. J. Phys. Oceanogr. 5:111-124. , and Murthy, C.R. 1974. Observations of lateral shear in the nearshore zone of a Great Lake. J. Phys. Oceanogr. 4:660-664.

Blumberg, A.F., and Mellor, G.L. 1987. A description of a three-dimensional coastal ocean model. In Three dimensional coastal ocean models, coastal and estuarine sciences, N. Heaps, ed., pp. 1-16. Washington, D.C.: American Geophys. Union.

Boyce, F.M. 1974. Some aspects of Great Lakes physics of importance to biological and chemical processes, $J$. Fish. Res., Board Can. 31:689-730.

, Donelan, M.A., Hamblin, P.F., Murthy, C.R., and Simons, T.J. 1989. Thermal structure and circulation in the Great Lakes. Atmos. Ocean. 27(4): 607-642.

Brink, K.H., Bane, J.M., Church, T.M. Fairall, C.W., Geernaert, G.L., Hammond, D.E., Henrichs, S.M., Martens, C.S., Nittrouer, C.A., Rogers, D.P., Roman, M.R., Roughgarden, J.D., Smith, R.L., Wright, L.D., and Yoder, J.A. 1992. Coastal Ocean Processes: a Science Prospectus, Woods Hole Oceanographic Institution, Woods Hole, MA, USA.

Carter, C.H., and Haras, W.S. 1985. Great Lakes. In The World's Coastline, E.C.F. Bird and M.C. Schwartz, eds., pp. 253-260. New York: VanNostrand Reinhold.

Churchill, J.H., Ralph, E.A., Cates, A.M., Budd, J.W., and Urban, N.R. 2003. Observations of a negatively buoyant river plume in a large lake. Limnol. Oceanogr. 48:884-894.

Crowe, A.S., and Shikaze, S.G. 2004. Linkages between groundwater and coastal wetlands of the Laurentian Great Lakes. Aquat. Eco. Health \& Manage. 7(2): 199-213.

Csanady, G.T. 1984. Circulation in the Coastal Ocean. Boston: D. Reidel Publishing Co. 1970. Dispersal of effluents in the Great Lakes. Water Res. 4:79-114.

1972. The coastal boundary layer in Lake Ontario, 2, The summer-fall regime. J. Phys. Oceanogr. 2:168-176.

and Scott, J.T. 1974. Baroclinic coastal jets in Lake Ontario during IFYGL, J. Phys. Oceanogr. 4: 524-541.

Donelan, M.A. 1977. A simple numerical model for wave and wind stress prediction. NWRI technical Report, NWRI, Burlington, On, Canada.

Eadie, B.J., Schwab, D.J, Leshkevich, G.L., Johengen, T.H., Assel, R.A., Holland, R.E., Hawley, N., Lansing, M.B., Lavrentyev, P., Miller, G.S., Morehead, N.R., Robbins, J.A., and VanHoof, P.L. 1996. Anatomy of a recurrent episodic event: a winterspring plume in southern Lake Michigan, EOS. Transactions of the American Geophysical Union 77: 337-338. 
Gbah, M.B., and Murthy, C.R. 1998. Characteristics of turbulent cross and alongshore momentum exchanges during a thermal bar episode in Lake Ontario. Nordic Hydrology 29:57-72.

Green, S.A., and Eadie, B.J. 2004. Introduction to special section: Transport and transformation of biogeochemically important materials in coastal waters, J. Geophys. Res. 109:C10S01. doi:10.1029/2004JC002697.

Hamblin, P.F. 1987. Meteorological forcing and water level fluctuations on Lake Erie. J. Great Lakes Res. 5: 302-315.

Hawley, N., and Lesht, B.M. 1995. Does local resuspension maintain the benthic boundary layer in Lake Michigan. J. Sediment. Res. 65:69-76.

, Lesht, B.M., and Schwab, D.J. 2004. A comparison of observed and modeled surface waves in southern Lake Michigan and the implications for models of sediment resuspension. J. Geophys. Res. 109:C10S03,

Hayashida, T., Atkinson, J.F., DePinto, J.V. and Rumer, R.R. 2000. A numerical study of the Niagara River discharge near-shore flow field in Lake Ontario. $J$ Great Lakes Res. 25:897-909.

He, C., Rao, Y.R., Howell, T.,. and Skafel, M.G. 2006. Numerical modeling of Grand River plume during unstratified period. Wat. Qual. Res. J Can. 41 (1): 16-23.

Heckey, R.E., Smith, R.E.H., Barton, D.R., Guildford, S.J., Taylor, W.D., Charlton, M.N., and Howell, T. 2004. The nearshore phosphorous shunt: a consequence of ecosystem engineering by dreissenids in the Laurentian Great Lakes. Can. J. Fish. Aquat. Sci. 61: 1285-1293.

Henderson-Sellers, B. 1984. Engineering Limnology, London: Pitman Advanced Publishing Program.

Holman, R.A. 1995. Nearshore processes, Reviews of Geophysics-Supplement, Vol. 33: 95RG00297.

Holland, P.R., and Kay, A. 2003. A review of the physics and ecological implications of the thermal bar circulation. Limnologica 33:153-162.

Hubertz, J.M., Driver, D.B., and Reinhard, R.D. 1991. Hindcast wave information for the Great Lakes: Lake Michigan. WIS Report 24. U.S. Army Corps of Engineers, Washington, D.C.

Klump, J.V., Bedford, K.W., Donelan, M.A., Eadie, B.J., Fahnenstiel, G.L. and Roman, M.R. 1995. Coastal Ocean Processes (CoOP): Cross-Margin Transport in the Great Lakes. CoOP Report Number 5.

Lam, D.C.L., and Jaquet, J.M. 1976. Computations of physical transport and regeneration of phosphorous in Lake Erie, Fall, 1970. J. Fish. Res. Board Can. 33: 550-563.

, and Schertzer, W.M. 1999. Potential climate change on Great Lakes hydrodynamics and water quality. NWRI contribution No. 99-059, NWRI, Burlington.
Murthy, C.R., and Simpson, R.B. 1984. Effluent transport and diffusion models for the coastal zone. New York: Springer Verlag.

Lee, C.H., and Hawley, N. 1998. The response of suspended particulate material to upwelling and downwelling events in southern lake Michigan. J. Sedimentary Res. 68:819-831.

Lee, K.K., Shen, B., and Wu C.S. 1996. Nearshore hydrodynamic and water intake evaluation and design. In Proceedings of North American Water Resources Evaluation and Design, American Society of Civil Engineers.

Lesht, B.M., and Hawley, N. 1987. Near bottom currents and suspended sediment concentration in southeastern Lake Michigan. J. Great Lakes Res. 13:375-383.

Lorke, A, Peeters, F., and Thorwat, J. 2005. Dynamics of high-frequency internal waves in the littoral zone of a large lake. $9^{\text {th }}$ workshop on Physical processes in Natural Waters, eds. A. Folkard and I. Jones, Lancaster University.

Lou, J., Schwab, D.J., Beletsky, D., and Hawley, N. 2000. A model of sediment resuspension and transport dynamics in southern Lake Michigan. J. Geophys. Res. 5:6591-6610.

Liu, P.C. 1999. Wind-waves in large lakes. In Potential climate change effects on Great Lakes hydrodynamics and water quality, D.C.L. Lam and W. M. Schertzer, eds. ASCE, 5.1- 5.15.

Masse, A.K., and Murthy, C.R. 1990. Observations of the Niagara River thermal plume, Lake Ontario, North America. J. Geophys. Res. 95:16,097-16,109.

Moll, R.A., Braktkovich, A., Chang, W.Y.B., and Pu, P. 1993. Physical, chemical and biological conditions associated with the early stages of the Lake Michigan vernal thermal front. Estuaries 16:92-103.

Mortimer, C.H. 1963. Frontiers in physical limnology with particular reference to long waves in rotating basins. In Proc. 5th Conf. Great Lakes Res., pp. 9, Great Lakes Research Division Publ. No 5. 1984. Measurements and models in physical limnology, In Hydrodynamics of lakes, K. Hutter, ed. Wien-New York: Springer-Verlag.

1988. Discoveries and testable hypothesis arising from Coastal Zone Color Scanner imagery of southern Lake Michigan, Limnol. Oceanogr. 33:203-226.

Murthy C.R., and Dunbar, D.S. 1981. Structure of flow within the coastal boundary layer of the Great lakes. J. Phys. Oceanogr. 11:1567-1577.

, and Rao, Y.R. 2003. Circulation and turbulent diffusion in the coastal ocean. In Proc. Ind. Nat. Sci. Acad. 69, pp. 633-644.

and Schertzer, W.M. 1994. Physical limnology and water quality modelling of North American Great Lakes. Part 1: Physical processes. Water Poll. Res. J. Canada, 29:129-156.

Simons, T.J., and Lam, D.C.L. 1986. Dynamic 
and transport modelling of the Niagara River Plume in Lake Ontario. Rapp. P-v. Reun. Cons. Int. Explor. Mer. 186:150-164.

Paul, J.F., and Lick, W.J. 1974. A numerical model for thermal plumes and river discharges. In Proc. $17^{\text {th }}$ Conf. Great Lakes Res., pp. 445-455. Internat. Assoc. Great Lakes Res.

Rao, Y.R. and Murthy, C.R. 2001a. Coastal Boundary Layer Characteristics during Summer Stratification in Lake Ontario. J. Phys. Oceanogr. 31:1088-1104. , and Murthy, C.R. 2001b. Nearshore currents and turbulent exchange characteristics during upwelling and downwelling events in Lake Ontario. J. Geophys Res. 106(C2):2667-2678.

, and Schwab, D.J. 1976. Two-dimensional normal modes in arbitrary enclosed basins on a rotating earth: Application to Lakes Ontario and Superior. Phil. Trans. R. Soc. London. 28:63-96.

, Murthy, C.R., and McCormick, M.J. 2003a. Circulation during winter and episodic events in southern Lake Michigan. J. Geophys. Res. 109:C01010, doi:10.1029.

Skafel, M.G., Howell, T., and Murthy, C.R. 2003b. Physical processes controlling taste and odour episodes in Lake Ontario drinking water. J. Great Lakes Res. 29:70-78.

, Murthy, C.R., Chiocchio, F., Skafel, M.G., and Charlton, M.N. 2003c. Impact of proposed Burlington and Hamilton sewage discharges in western Lake Ontario. Wat. Qual. Res. J. Canada 38:627-645.

, Skafel, M.G., and Charlton M.N. 2004. Circulation and turbulent exchange characteristics during the thermal bar in Lake Ontario. Limnol. Oceanogr. 49: 2190-2200.

Resio, D.T., and Vincent, C.L. 1976. Design wave information for the Great Lakes; Report 2, Lake Ontario. Technical report H-76-1, U.S. Army Engineer Waterways Experiment Station, Vicksburg, MS.

Rodgers, G.K. 1968. Heat advection within Lake Ontario in spring and surface water transparency associated with the thermal bar. In Proc. $11^{\text {th }}$ Conf. Great Lakes Res. pp. 942-950. Internat. Assoc. Great Lakes Res.

Saylor, J.H., Huang, J.C.K., and Reid, R.O. 1980. Vortex modes in Lake Michigan. J Phys. Oceanogr. 10(11): 1814-1823.

Scavia, D., and Bennet, J.R. 1980. Spring transition in Lake Ontario: A numerical study of the causes of the large biological and chemical gradients. Can. J. Fish. Aquat. Sci. 37:823-833.

Schwab, D.J. 1978. Simulation and forecasting of Lake Erie storm surges, Mon. Wea. Rev. 106:1476-1487. 1992. A review of hydrodynamic modelling in the Great Lakes from 1950-1990 and the prospects for 1990's. In Computer modelling of seas and coastal regions II, eds. Gobas A.P.C. and McCorquadale, pp. 387-395, A. Computational mechanics publications, Southampton. and Bedford, K.W. 1994. Initial implementation of the Great Lakes forecasting system: A real-time system for predicting lake circulation and thermal structure. Wat. Poll. Res. J. Canada 29:203-220.

, Bennet, J.R., Liu, P.C., and Donelan, M. 1984a. Application of a simple numerical wave prediction model to Lake Erie, J. Geophs. Res. 89:3586-3592. Meadows, G.A., Bennet, J.R., Schultz, H., Liu, P.C., Campbell, J.E. and Dannelongue, H.H. 1984b. The response of the coastal boundary layer to wind and waves: analysis of an experiment in Lake Erie, $J$. Geophys. Res. 89:8043-8053.

Beletsky, D., and Lou, J. 2000. The 1998 Coastal Turbidity Plume in Lake Michigan. Est. Coast. Shelf Sci. 50:49-58.

Scott, D., Schwab, D.J., Zuzek, P., and Padala, C. 2004. Hindcasting wave conditions on the north American Great Lakes. In Proc. $8^{\text {th }}$ Int. workshop and wave hindcasting and forecasting, Hawaii, USA.

Simons, T.J. 1980. Circulation models of lakes and inland seas. Can. Bull. Fish. Aquat. Sci. No. 203.

1984. Topographic response of nearshore currents to wind: An empirical model. J. Phys. Oceanogr. 14:1393-1398.

, and Schertzer, W.M. 1989. The circulation of Lake Ontario during summer of 1982 and the winter of 1982/83. Scientific series, 171, pp. 191, National Water Research Institute, CCIW, Burlington.

Shen, H., Tsanis, I.K., and D'Andrea, M. 1995. Three dimensional nested hydrodynamic/pollutant transport simulation model for the nearshore area of Lake Ontario. J. Great Lakes Res. 21:161-177.

Sheng, J., and Rao, Y.R. 2006. Circulation and thermal structure in Lake Huron and Georgian Bay: Application of a nested-grid hydrodynamic model. Cont. Shelf Res. 26:1496-1518.

Stepien, I., Lam, D. C. L., Murthy, C. R., Fox, M.E., and Carey, J. 1987. Modelling of Toxic Contaminants in the Niagara River Plume in Lake Ontario. J. Great Lakes Res. 13:250-263.

Watson, S.W, Howell, T., Charlton, M.N., Skafel, M.G., and Rao, Y.R. 2002. Taste and Odour outbreaks in N.W. Lake Ontario, Physical, chemical and biological drivers. 39th central Canadian symposium on water quality research, Burlington, Ontario.

Submitted: 28 April 2006

Accepted: 5 December 2006

Editorial handling: Barry M. Lesht 